\title{
Factors that Influence Fan's Attendance at Individual Sporting Events in Egypt through Coaches' and Media Perspective
}

\author{
Ezzeldin R. Aly, PhD, \\ Associate Professor of Sport Management, \\ Department of Health, Physical Education and Recreation, \\ College of Education, Florida A\&M University, USA \\ Desmond S. Hodge, PhD, \\ Psychological and Soical Work Services, \\ Marion County School District, Ocala, USA
}

\begin{abstract}
Egypt has been long reflected as one of the most attractive countries to visit because of its historical treasure. Egypt also has remarkable athletic performances in the world championship and the Olympics. Egypt's first recent Olympic gold medal was during the Athens Olympic Games. However, fans' attendance at individual sporting events was not equivalent to fan presence at team sports. Related studies about fans' who participate in different sporting events focused on men's sports, team sports, and professional sports (Armstrong, 2007). The sports development pyramid model by Casey (1988), designed to analyze the stages of sports development, was used to understand more about the association of the significance of specific factors that Influence fans', and fan attendance at different individual sporting events in Egypt. A survey initially designed by the researchers was used to collect insights from seven (7) sports journalists, and twenty-seven (27) national team head coaches from different countries, who attended the African and the Arab games held in Cairo, Egypt. The results showed a significant relationship between fan attendance and individual sporting events, public relations, social media, cultural, and the actions of the Egyptian National Governing Bodies (ENGB). The result of this study further suggests the importance of implementing marketing strategies to promote individual sport.
\end{abstract}

Keywords: Fans, Gameday Experiences, Sports Events, Sports Marketing, International Sports and Sport Media 


\section{Introduction}

The Golf World has voted Egypt as one of the ten sunniest golf destinations in which to break free during winter months, along with other destinations, such as California, Florida, and Dubai (Golf World, 2002). International sports are also highly celebrated in Egypt. Egyptian Olympic athletes and sports teams have won medals and showed outstanding performance not only in the Olympics but also on the World Cup levels. However, despite Egyptian success in international sports such as the Olympic Games, travel to Egypt is routinely for tourism and leisurely purposes. Unlike professional sport in the United States which hold immense prominence, the achievements of Egyptian international sports are frequently unnoticed.

In Egyptian individual Olympic sports, Greg Romany showed exceptional performance in wrestling, winning a gold medal for Egypt during the 2004 Athena Olympic Games. Boxers from Egypt also won medals in Athena 2004. In 2008, Egypt had fifteen of the top twenty squash players in the world and was expected to dominate the Squash tournament of champions at Grand Station on January 14 of this same year, leaving fans wondering, "what are Egypt's water secrets (Egypt Produces Squash Champions, 2008." Recently achieving its seventh win in 12 years at the biggest Squash tournament, Egyptian women and men's Squash is currently among the world leaders in both individual and team sport-It's secret lies in politics and geography (Sopher, 2014).

In Egypt, the sport is regarded as an upper-class game, occupied by those who can afford admission and compensation fees for the same sporty clubs that the British built around the turn of the 20th century. Notwithstanding, the work by individuals such as Mubarak who-despite his removal or resignation in 2011-helped facilitate increasing acceptance of squash in the country; although, not its access. Nevertheless, Egypt's international dominance in Squash and national respect in sports persist to this day because of gifted athletes.

Similarly to the athletes from other continents, Egyptian athletes and organizations need to go through several steps to get qualified to represent Egypt in competitions at the Olympic Games or international sporting events. First, athletes need to be classified on the top performers in the sports they participate in and must become a member of the Egyptian national team. Secondly, athletes must represent Egypt of North Africa as a country too and achieved the Olympic qualification standards for the next level. Thirdly, after winning the events or games they get to compete in the Arab Games; then the African (Continental) competition; and finally, attain qualification through the International Olympic Committee (IOC) to represent Egypt in the Olympics. Egyptian Olympic athletes and sports teams have to work hard to be qualified to represent the Egyptian national team in the Olympic Games. However, 
despite the success of the athletes and team sports in the Olympic Games and international events, fan attendance for individual sports competitions including swimming, fencing, wrestling, judo, weightlifting, track and field, squash, diving, synchronizing swimming, tennis, boxing, karate, and gymnastics has not reached the expected attendance rate. In Egypt, there is less attendance for individual sporting events, unlike team sports, which usually attracts significantly more fans. Furthermore, most of the sports facilities are located in northern urbanized cities such as Cairo and Alexandria. The southern more rural regions of the country have limited availability of recreational facilities and access to sports involvement opportunities; a disparity that further underscores issues regarding the economy and rights of disadvantaged populations (Aly, 2014).

\section{Review of literature}

\section{Fans}

According to a recent study conducted by the University of Oregon on Student Attendance at Collegiate Sporting Events, students are more likely to attend a game if they get free $t$-shirts at the game, receive concession discounts, whether live music or a disc jockey (DJ) will be present at the event, or if there is a post-game party (Guerra, 2015). According to the bleacher report, the number one "game day experience" is from the University of Alabama, which has hosted more than 101,000 fans screaming at the top of their lungs at Bryant-Denny Stadium, facilitating an excellent game-day experience (Vasta, 2017). What is more, at Alabama state, the "SEC famed University of Alabama coach Nick Saban wrote a heartfelt letter to the school's newspaper, asking students to return to the stands and help cheer on their peers. According to the Wall Street Journal, at campuses across the country, more reasons than ever exist to skip the game. Therefore, seeking to increase attendance through "game day experience" at a home football game require athletic departments to look closely at the factors that affect game-day attendance (Groza, 2010).

Through Game-day Experience, athletic departments may be able to improve attendance at football games thereby increasing monetary resources, which subsequently support, while not necessarily promoting, better management of revenues and expenditures (Fall \& Natke, 2014). South Carolina State University (CSU), for example, issued a memo that indicated CSU's intent to enhance the game-day experience through the Game Zone. According to the notice, the Game Zone is the boundary defined within and around Bulldog Stadium, where fans can actively and safely enjoy SC State football games and tailgating. CSU also mentioned a focus on Customer Service. To enhance game-day experience, the university suggested that all 
CSU stakeholders avoid staying in lines by buying game tickets in advance of game day.

Fan attendance and game experience may also be necessary for the recruitment process at the universities (Falls \& Natke, 2014). In a predictive study about fans' attendance rate at women sports, an analysis was conducted of the relationship between specific factors and fans attendance at selected NCAA Division I women's sporting events. The study results revealed that an early-season winning ratio and the presence of other Division I institutions predicted attendance for women's sports. Student's enrollment, however, predicted more participation for each sport except women's soccer.

Egypt has newly added women's soccer to Egyptian national sports. Only men have traditionally played soccer in Egypt; women were prevented from participating in sports and many Egyptian females experienced prejudice for playing the sport (Klein, 2007). Madame Sahar El-Hawari, was the first to bring notice of soccer to Egypt helping form Egypt's women's national soccer team and then going to the women's African Cup of Nations ( Mazhar, \& Inas 2004). In addition, the Federation of International Football Association (FIFA) assessed the Egyptian women's national soccer team and stated that the women's soccer team is good but could be better in general (Al-Aharam, 2012). Softball is not yet included as an Egyptian national sport ( Shackelford \& Greenwell, 2005).

\section{Olympic and Other International Sports in Egypt}

Egypt has had excellent Olympic performances in early 1910 when Egypt became a member of the International Olympic Committee. During the 1928 Olympic Games in Amsterdam, gold medals were awarded to the Egyptian fencer Mohamed Ahamed Assanien and weightlifters Ibrahim Mustafa in their respective (individual) sports (Egyptian NOC, 2018) - see appendix I (Table 1) for Egyptian medal recipients from the Olympic Games and other international events. Furthermore, Karim Darwish was among the list of number one ranked men's squash player's in the world, after winning the Italy 2000 Squash championship. In 2007, the Egyptian men's $10 \mathrm{~km}$ Open Water Marathon team achieved the world bronze medal and the Egyptian marathon team qualified to participate at the Bejing 2008 Olympic Games. Egyptian team sports have also had formidable success on the professional level; for example, in 1998 the Egyptian Handball team won the World Junior Cup award.

Although Egyptian athletes have had notable success in individual sport, team sports seemed to draw the most attraction. In a 2018 study, Revolvy found that of the 23 stadiums located throughout Egypt, all were used for soccer sport. However, these stadiums could also be used for some other individual sports and sporting events. For example, in 2006 the African 
Nations Cup-considered a mega event-was hosted at the Cairo International Stadium. The Cairo International Stadium holds a capacity of 74,000 spectators and is usually fully attended during significant sporting events; it is regarded as one of the largest Stadiums in the Middle East and Africa (Revolvy, 2018).

Nevertheless, even with the state of the art sports facilities and the success of Egyptian athletes in international competitions, Egyptian sports fans are not enthusiastic about watching individual Olympic Sports. Maybe fans do not recognize a particular sport because of limited exposure. Media and press coverage are generally provided for team sports; specifically, soccer - internationally known as football. Team sporting events are not only saturated across the media airways but are also promoted heavily via advertisements on TV and the worldwide internet of things.

Egyptian governmental effort has been ongoing at making attempts to develop and expand programming and facilities to meet the needs of the people (Chan \& DeGraaf, 1998). Federal Government efforts are also continuously being exerted at broadening the continuum of accessible recreational and entertainment opportunities for families during their vacation times. From the (IOC) news about the Olympic movement, the TV and viewing were projected to break records for the Athens 2004 Olympic Games. Several countries were forecasted to carry extensive live footage for the first time, including Egypt (at 80\% coverage). Expanding sports media attention and coverage in Egypt will ensure that many more people as possible could share in the Olympic experience through television, as well as, share in the great achievements of Olympic athletes, particularly those competing in individual sports.

\section{Possible Reasons That Egyptian Sports Fans do Not Attend Sports and Games}

Unlike in other developed countries, where as after the sports event, games, or competition athletes and coaches have the chance to meet fans and engage in public relations, this does not happen in Egypt. Sports media in Egypt primarily focus on pratical aspects of sports with less emphasis on sports journalism. However, Egyptian sports media should broaden its comentary by communicating less about the scientific documentary and include more sports analysis and discourse on sport public relations, particularly for individual sports. Promoting and providing opportunities for fans to know and understand sports could further increase interest in sports participation.

Currently, however, there is limited information, as well as sport management professionals to provide substantial suggestions to the government for implementing a marketing plan for national TV broadcasting 
and promotion of Egyptian sports culture (e.g. sports journalism and research, information on teams and player statistics, and opportunities for fans to get to know about team coaches).

According to Casey's (1988) sports development model (shown below) Foundation, Participation, Performance, and Excellence are very significant for sports development. Although, the marketing plan plays a vital role in sports and the sports promotion process. Casey's Model could also be applied to sports marketing and promotion.

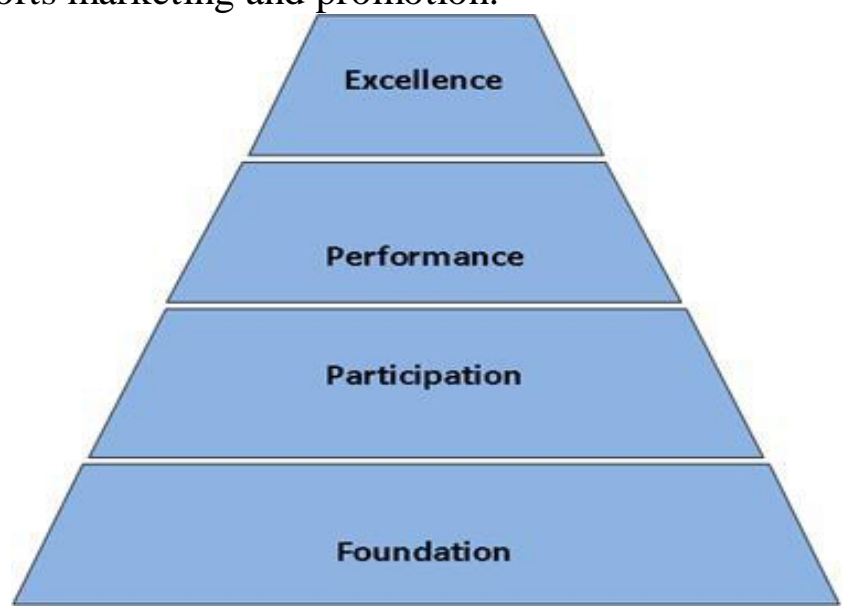

Foundation: The foundational stage (Level one) of Casy's sports model relates to the foundation level of the researcher's sport marketing plan, including several other elements and phases in the plan. The foundation level of the marketing plan starts with a statement of the problem and defining of goals (Armstrong \& Kotler, 2018).

Participation: The next level of Casy's model (participation) relates to sports marketers' analysis of the current mitigating situations/conditions for the implementations of the marketing plan.

Performance: In the Performane stage, the third level of Casey's Model, once the mitigating conditions have been identified, the target market and demographics should be determined. In this current study, rebranding was the primary target for the Egyptian sports marketing plan.

Excellence: In the Excellence stage (level four), based on Casy's model the marketing goal for increasing and sustaining fandom for Egyptian teams and leagues, as well as improving organizational and player value was to link sports to nostalgic past times that Egyptian fans can relate to and reconnect with.

Despite the fluctuation of the recent Egyptian market in sport, there has been no examination of it to date. The five functional areas of the latest retro marketing ideas that affect the excellent level of Casey's sports development model on Egyptian fans and attendance percentage in the 
competition were: imagery, merchandising, venue, game day experience, promotions, and advertising.

Furthermore, Casy's Sport Development plan and this recent study conceptual are in parallel with the four domains of sports marketing, which were designed by Sam Fullerton and G. Russell Merz in 2008 and identifies the tactics used by sports companies while categorizing them into four key domains (a) theme-based, (b) product-based, (c) alignment-based, and (d) sports-based; the first two are traditionally used, while the last two are more sponsorship based (Figure 2).

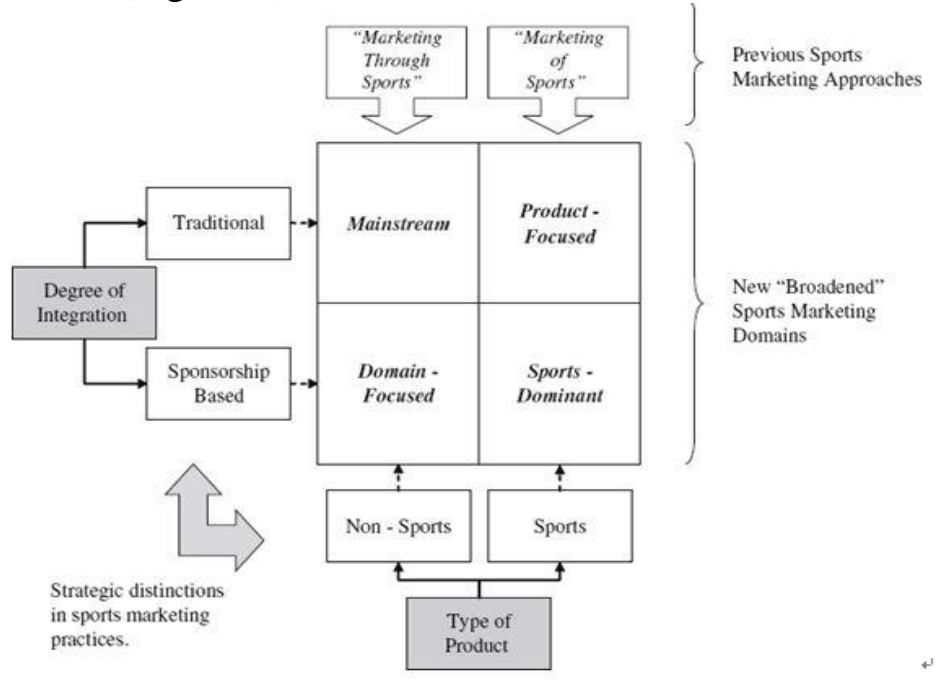

Figure 2 illustrates a grounded theory-based theoretical framework classifying activities that comprise sports marketing. It predicates on the notion that sports related marketing is not solely focused on how to get more fans in the seats at specific sports organized events such as a through concert, conference, or sports events. Sports marketing is also linked to the promotion and retail of sporting goods. Therfore, taking the type of sports product sold and the level of sports integration into account, four strategic domains have been identified (1) the types of products that have been established as sports products and nonsports products, (2) the marketers' level of integration concerns its involvement with some sports entity in some form of official sponsorship. As such, the two broad areas for interaction have been designated as a traditional area for cooperation, which has been indicated as conventional and sponsorship-based.

At the most fundamental level of strategies, includ the use of the longestablished components of a marketing strategy-target as market and marketing mix decisions-to sell sport and nonsporting products. In Egypt there is much work to be done at the foundational level of sport marketing stratiges. 
Describing a higher level of integration, many countries have aligned their brand with sports brands via sports sponsorship plans.

Alignment-based strategies use sponsorship plans to sell nonsports products; marketers has a direct link to some sports entity that qualifies this type of marketing policy. Conversely, sports-based operations policy involves some form of official sponsorship plan that crowd the marketplace.

Besides, the broadened set of sports marketing domains articulated herein provides a method for classification system as an initial first step for the sports marketing development theory in the sports field; also, it guides decisionmakers in the sports business.

This present study also used those sport marketing dimensions during the interview, as well as included them in the survey because they encompassed the retro marketing practices, are frequently trusted upon elements of marketing and have significant impacts on sports consumers (Brian Gordon \& Zach Scola, 2018). From the results of this research, sports marketers could develop more appropriate marketing strategies to promote and attract sports fans to attend the Arab Championship Cub”.

In an article written in Egypt Today (2018), many questions loom regarding the unwillingness of promoters and corporations to sponsor Egyptian Individual Sports athletes despite their personal accomplishments in contests. One reason for the lack of athletic sponsorship is that individual Sports in Egypt are not standard, which caused the contestants to lose interest. However, sports federation leaders and governing bodies of individual sports analyzed the situation in several ways. Mohamed Abdel Aziz Ghoneimboxing federation president—said, "The main reason for the absence of entrepreneurs and corporations to sponsor individual sports stars is the lack of media coverage, mainly because these champions are not appearing on television screens." Notwithstanding, everybody knows that sponsors prefer soccer or more fittingly Football; it is full of stars.

The greatest indication of the lack of media coverage is the uproar that happened after the champions won medals at the Mediterranean Games in Spain, whom presently no one talks about"'. Mohamed Mahgoub weightlifting federation president, said, "It is all about how much money the supporters would gain out of the individual sports. Sponsors pay cash for what fans prefer; the fans' cheerfulness only during the day of the success. Regarding individual sports media broadcasting, Hany Hamouda - hockey Federation president - said, there is a "Culture of love for the popular game, soccer, which as a sport, is the most significant factor in the absence of sponsors in individual sports. The change in the cultural views and outlook of individual sport culture will be accomplished if there is a generational belief in the ideology of individual sports." Abdel Moneim Elhosseiny - fencing federation president-said, "fan's attention affects the sponsors a lot. 
Regrettably, this difficulty will long last as most Egyptian fans believe only in soccer."

\section{Sports Fans Motivation to Attend Sports Events}

A study by Grieve et al. (2008) identified eight fan motives to attend sports events. These eight motives included escape, economics (i.e., gambling), eustress (i.e., positive arousal), self-esteem, group affiliation, entertainment, family, and aesthetics. Results from Grieve et al. (2008) study also showed differences between the types of sports. For example, aesthetic motivation was found to be particularly prominent in individual sports, while scores were more significant for team sports in eustress, self-esteem, group affiliation, entertainment, and family." There might be various reasons that Egypt has difficulty in attracting fans to participate in sports. Most previous studies focused on promotional efforts.

However, Vail (2007) suggested that developing collaborative partnerships and delivering quality sports programming is an essential mechanism for attracting fans to participate in sports. Furthermore, sports fan's attendance at sporting events might be because fans want to support the sport or athletes with special skills for playing particular positions or specific styles of play, or they are just interested in watching the game. The sports marketing plan will not only serve to improve and maintain current attendance levels at Egyptian sporting events but will also increase attendance level at individual level sports in Egypt. Different sports events sponsorship has grown into a multi-billion dollar industry; revenues grew by $18 \%$ between $1988-1991$ and showed a $9 \%$ increase ( $\$ 6$ billion) by 1997 . These revenue projections provide evidence for the importance of sponsorships in international sports industry and the Olympics, as is the case in the United States (US), including the effect on sports fandom (Dodd, 1997).

\section{Promoting Olympic Individual Sports in Egypt}

To boost popularity for individual sports, it is crucial to encourage and increase fan attendance because the more fans attend and watch sports events, sports competitions, and games the more fans, family, and friends understand sports. Moreover, an individual athlete has to work and train very hard to qualify for the Olympic Games or competition at the international level. Therefore, helping spectators (fans) to better understand the athletes and sports each of them compete in could help to facilitate more interest and partcipation from fans; subsequently, increasing the popularity of individual sports. Increasing sports fan knowledge and competence could further stimulate endorsement opportunities and sponsorships for the athletes and increased revenues for the Egyptian National Governing Body (NGB) of sport to succeed. 
It is essential to understand sports fans' motivations to participate in Olympic sporting events because it will be helpful for the sports managers to design the appropriate marketing plan and promotion strategies to reach the fans. It will also be beneficial for the Egyptian government to increase the participation of individual sports in Egypt. Furthermore, there are more medals in individual than in team competition on the international level; for example, swimming has many events in the Olympic Games versus one medal for a basketball team. Increased media coverage and recognition for the teams, lead to more deals for the Egyptian athletes.

\section{Methodology}

Recent study sampling: Forty people (thirty-three team head coaches and seven media persons) attended the Arab Game Championship Cub Conference. Sports events included 'taekwondo, squash, gymnastics, shooting, archery, tennis, camel riding, handball, and table tennis. A total of (34) individuals participated in the survey. Twenty-seven participants were head coaches of national individual sports teams in Egypt and seven (7) were journalists. The respondents were first asked to complete a (27) question survey, which included four open-ended questions. Next, the researchers conducted 45-minute personal interviews which each partcipant, based on the answers from the four open-ended questions.

Data collection primarily included two steps. The first step was implementation of a twenty-seven (27) item survey, which was developed by the primary researcher of the current study. The researcher administrated the survey during the Arab National Cub Conference at Cairo, Egypt, which is hosted every two years in a different Arab country. The survey questions focused on media coverage for individual sports, the role of public relations, team managers and promotion of individual sports, also questions fan perceptions of attendane at individual sports, organizing of the Arab Games it Egypt, coaches' perceptions about the marketing plan and the connection between fans and attendance at individual sporting events. Other survey questions focused on the cost of tickets to attend individual sports events.

The reliability of the survey was established using a combination of inter-observer reliability, (six observers), face validity using a pilot test, clean collected data, principal components analysis (PCA), and the Cronbach's Alpha test. Of the twenty-nine survey questions two questions were eliminated from the survey and reliability testing yielded a high relaibility rating (Cronbach's Alpha $\alpha>0.9$ ). Coaches, head coaches and journalists, signed a consent form indicating that they voluntarily agreed to participate in the study. The consent form also indicated that participants had the exclusive right to withdraw at any time from the study. The consent form was delivered to all the research subjects before they participated in the survey process. 
The researcher provided the participants a pencil to complete the survey and collected all the completed surveys in a sealed envelope. No names or personal data were required to participate in the study.

The research data were analyzed using descriptive statistics (for the survey results see Appendix II). The second step of the study was to conduct personal interviews to obtain more in-depth, specific information for the suggestion about the marketing and promotion strategies for the individual sport. The (27) head coaches and (7) Journalist in the conference were asked to respond to questions regarding the status of fans' participation of their respective sports. Interview questions were: Why do we have a low attendance rate of competitions and games in different sports? Why do we have fewer attendance fans in your sports? Why have less attendance in individual sport occured compared to team sports? What are your suggestions to increase fans' presence for individual sports?

\section{Results}

Table 1 revealed that eighty-eight percent $(88 \%)$ of the participants agreed there is fewer media coverage for individual sport than for a team sport. Twelve-percent $(11.7 \%)$ disagreed that there is fewer media coverage for different sports events than team sports.

Table 1: Media coverage for individual sports and team sport

\begin{tabular}{|c|c|c|c|c|c|}
\hline \multicolumn{2}{|c|}{ Yes } & \multicolumn{2}{c|}{ Avg. } & \multicolumn{2}{c|}{ No } \\
\hline Frequency & Percentage & Frequency & Percentage & Frequency & Percentage \\
\hline 30 & $88.24 \%$ & 0 & $0.00 \%$ & 4 & $11.76 \%$ \\
\hline
\end{tabular}

Table 2 showed that forty-seven percent (47.06\%) of study participants agreed there is a relationship between public relations and various sports. Fifty-three percent $(52.94 \%)$ indicated they did not know if there was a relationship between public and individual sports.

Table 2: The relationship between public relations and individual sports

\begin{tabular}{|c|c|c|c|c|c|}
\hline \multicolumn{2}{|c|}{ Yes } & \multicolumn{2}{c|}{ Avg. } & \multicolumn{2}{c|}{ No } \\
\hline Frequency & Percentage & Frequency & Percentage & Frequency & Percentage \\
\hline $\mathbf{1 6}$ & $47.06 \%$ & 18 & $52.94 \%$ & 0 & $0.00 \%$ \\
\hline
\end{tabular}

Table 3 showed that forty-one percent $(41.18 \%)$ of participants did not know if there was any coordination in work between team managers and media managers. Fifty-nine $(58.82 \%)$ disagreed that there was coordination in action between the head coaches and the media team managers. 
Table 3: Is The coordination between team managers and media coverage

\begin{tabular}{|c|c|c|c|c|c|}
\hline \multicolumn{2}{|c|}{ Yes } & \multicolumn{2}{c|}{ Avg. } & \multicolumn{2}{c|}{ No } \\
\hline Frequency & Percentage & Frequency & Percentage & Frequency & Percentage \\
\hline 0 & $0.00 \%$ & 14 & $41.18 \%$ & 20 & $58.82 \%$ \\
\hline
\end{tabular}

Table 4 showed that forty-one percent (41.18\%) of participants agreed there was a delay in sending results to the media. Fifty-eight percent $(58.82 \%)$ of the coaches disagreed that they knew whether conference results were delivered late to the press.

Table 4: The coordination between team manager to transport all results for media directly.

\begin{tabular}{|c|c|c|c|c|c|}
\hline \multicolumn{2}{|c|}{ Yes } & \multicolumn{2}{c|}{ Avg. } & \multicolumn{2}{c|}{ No } \\
\hline Frequency & Percentage & Frequency & Percentage & Frequency & Percentage \\
\hline $\mathbf{1 4}$ & $41.18 \%$ & 20 & $58.82 \%$ & 0 & $0.00 \%$ \\
\hline
\end{tabular}

Table 5 showed that eighty-eight percent $(88.24 \%)$ of participants disagreed about how much fans know about the individual sport. In addition to how much effort players put into respective sports.

Table 5: Fans know about the individual sports

\begin{tabular}{|c|c|c|c|c|c|}
\hline \multicolumn{2}{|c|}{ Yes } & \multicolumn{2}{c|}{ Avg. } & \multicolumn{2}{c|}{ No } \\
\hline Frequency & Percentage & Frequency & Percentage & Frequency & Percentage \\
\hline 0 & $001.00 \%$ & 4 & $11.76 \%$ & 30 & $88.24 \%$ \\
\hline
\end{tabular}

Table 6 showed that forty-one percent (41.18\%) of participants agreed that most of the people attending the events were fans. Fifty-nine percent $(58.82 \%)$ disagreed whether the people who attended sporting events were all fans.

Table 6: People attending the events were fans

\begin{tabular}{|c|c|c|c|c|c|}
\hline \multicolumn{2}{|c|}{ Yes } & \multicolumn{2}{c|}{ Avg. } & \multicolumn{2}{c|}{ No } \\
\hline Frequency & Percentage & Frequency & Percentage & Frequency & Percentage \\
\hline 14 & $\mathbf{4 1 . 1 8 \%}$ & $\mathbf{0}$ & $\mathbf{0 . 0 0 \%}$ & $\mathbf{2 0}$ & $\mathbf{5 8 . 8 2 \%}$ \\
\hline
\end{tabular}

Table7 revealed that forty-one percent (41\%) of the partcipants agreed that the Arab Game Cub organizer is responsible for organizing people to participate as fans. Fifty-nine percent (58.82\%) did not know whether the Arab game cub organizers were responsible for people to join as fans. 
Table 7: The Arab Game Cub well organize for the fan to attending the events?

\begin{tabular}{|c|c|c|c|c|c|}
\hline \multicolumn{2}{|c|}{ Yes } & \multicolumn{2}{c|}{ Avg. } & \multicolumn{2}{c|}{ No } \\
\hline Frequency & Percentage & Frequency & Percentage & Frequency & Percentage \\
\hline 14 & $41.18 \%$ & 0 & $0.00 \%$ & 20 & $58.82 \%$ \\
\hline
\end{tabular}

Table 8 showed that eighty-eight percent $(88.24 \%)$ of the coaches thought their respective sport was famous. Over eleven percent $(11.76 \%)$ of the parctipants did not have an opinion on whether their game was famous.

Table 8: If your sport is famous

\begin{tabular}{|c|c|c|c|c|c|}
\hline \multicolumn{2}{|c|}{ Yes } & \multicolumn{2}{c|}{ Avg. } & \multicolumn{2}{c|}{ No } \\
\hline Frequency & Percentage & Frequency & Percentage & Frequency & Percentage \\
\hline 30 & $\mathbf{8 8 . 2 4 \%}$ & 4 & 11.76 & 0 & $0.00 \%$ \\
\hline
\end{tabular}

Table 9 showed that eighty-two percent $(82.35 \%)$ of the participant agreed that there is a relationship between less attendance and the promotion of their games or sports. Eighteen-percent $(17.65 \%)$ of the participant where neutral on the relationship between participation and development of their games or sports.

Table 9: The relationship between event attend and event promotion

\begin{tabular}{|c|c|c|c|c|c|}
\hline \multicolumn{2}{|c|}{ Yes } & \multicolumn{2}{c|}{ Avg. } & \multicolumn{2}{c|}{ No } \\
\hline Frequency & Percentage & Frequency & Percentage & Frequency & Percentage \\
\hline 28 & $\mathbf{8 2 . 3 5 \%}$ & $\mathbf{6}$ & $\mathbf{1 7 . 6 5}$ & $\mathbf{0}$ & $\mathbf{0 . 0 0 \%}$ \\
\hline
\end{tabular}

Table 10 indicated that seventy-three percent (73.53\%) of the participants agreed that their respective sports had the same chance to get famous as the other games. Twenty-six percent (26.47\%) were neutral on the potential of fame for their respective sports.

Table 10: Your sport could get famous as other sports

\begin{tabular}{|c|c|c|c|c|c|}
\hline \multicolumn{2}{|c|}{ Yes } & \multicolumn{2}{c|}{ Avg. } & \multicolumn{2}{c|}{ No } \\
\hline Frequency & Percentage & Frequency & Percentage & Frequency & Percentage \\
\hline 25 & $73.53 \%$ & 9 & $26.47 \%$ & 0 & $0.00 \%$ \\
\hline
\end{tabular}

Table 11 showed that eighty-two percent $(82.35 \%)$ of the participant agreed that Egypt had enough facilities for competition, especially individual sport. Eighteen percent (17.65\%) did do not know if Egypt had enough facilities to compete on the Arab national level. 
Table 11: Egypt has facilities for the competition especially the individual sports

\begin{tabular}{|c|c|c|c|c|c|}
\hline \multicolumn{2}{|c|}{ Yes } & \multicolumn{2}{c|}{ Avg. } & \multicolumn{2}{c|}{ No } \\
\hline Frequency & Percentage & Frequency & Percentage & Frequency & Percentage \\
\hline 28 & $\mathbf{8 2 . 3 5 \%}$ & 6 & $17.65 \%$ & 0 & $0.00 \%$ \\
\hline
\end{tabular}

Table 12 indicated that seventy percent (70.59\%) disagreed about the number of fans attending the Arab Game Cub. Twenty-nine (29.41\%) did not know about the fans who participated at the Arab Game Cub.

Table 12: The number of fans who attended the Arab Games.

\begin{tabular}{|c|c|c|c|c|c|}
\hline \multicolumn{2}{|c|}{ Yes } & \multicolumn{2}{c|}{ Avg. } & \multicolumn{2}{c|}{ No } \\
\hline Frequency & Percentage & Frequency & Percentage & Frequency & Percentage \\
\hline 0 & $\mathbf{0 0 . 0 0 \%}$ & 10 & $29.41 \%$ & 24 & $70.59 \%$ \\
\hline
\end{tabular}

Table 13 showed that seventy-percent (70\%) of the participants disagreed whether there was support from the federation in these sports events. Twenty-nine percent $(29.41 \%)$ did not know the amount of support individual sports received from their national league.

Table 13: Coaches have their federation support during the Arab Games

\begin{tabular}{|c|c|c|c|c|c|}
\hline \multicolumn{2}{|c|}{ Yes } & \multicolumn{2}{c|}{ Avg. } & \multicolumn{2}{c|}{ No } \\
\hline Frequency & Percentage & Frequency & Percentage & Frequency & Percentage \\
\hline 0 & $\mathbf{0 0 . 0 0 \%}$ & $\mathbf{1 0}$ & $\mathbf{2 9 . 4 1 \%}$ & $\mathbf{2 4}$ & $\mathbf{7 0 . 5 9 \%}$ \\
\hline
\end{tabular}

Table 14 showed that seventy-three percent $(73.53 \%)$ of the head coaches agreed that Egypt needed more stadium and sports facilities. Twentysix percent $(26.47 \%)$ were neutral in their responses.

Table 14: Egypt needs more stadiums and sports facility

\begin{tabular}{|c|c|c|c|c|c|}
\hline \multicolumn{2}{|c|}{ Yes } & \multicolumn{2}{c|}{ Avg. } & \multicolumn{2}{c|}{ No } \\
\hline Frequency & Percentage & Frequency & Percentage & Frequency & Percentage \\
\hline 25 & $\mathbf{7 3 . 5 3 \%}$ & $\mathbf{9}$ & $\mathbf{2 6 . 4 7 \%}$ & $\mathbf{0}$ & $\mathbf{0 0 . 0 0 \%}$ \\
\hline
\end{tabular}

Table 15 Indicated that fifty-nine percent $(58.82 \%)$ of the participant agreed that Egyptian stadiums need improvement or development. Twentynine percnt $(29.41 \%)$ disagreed in response to stadium improvements or developments. 
Table 15: Egypt stadiums need to improve and develop

\begin{tabular}{|c|c|c|c|c|c|}
\hline \multicolumn{2}{|c|}{ Yes } & \multicolumn{2}{c|}{ Avg. } & \multicolumn{2}{c|}{ No } \\
\hline Frequency & Percentage & Frequency & Percentage & Frequency & Percentage \\
\hline 20 & $58.82 \%$ & 10 & $29.41 \%$ & 4 & $11.76 \%$ \\
\hline
\end{tabular}

Table 16 showed that ninety-one percent $(91.18 \%)$ of the participants agreed that their country saw fewer fan attendance of the individual games. Nine percent $(8.89 \%)$ of the participants were neutral in response, or they do not know whether there was fewer fan presence at games.

Table 16: Other Arab countries have fewer fans attendance to the individual sports

\begin{tabular}{|c|c|c|c|c|c|}
\hline \multicolumn{2}{|c|}{ Yes } & \multicolumn{2}{c|}{ Avg. } & \multicolumn{2}{c|}{ No } \\
\hline Frequency & Percentage & Frequency & Percentage & Frequency & Percentage \\
\hline 31 & $\mathbf{9 1 . 1 8 \%}$ & $\mathbf{3}$ & $\mathbf{8 . 8 9 \%}$ & $\mathbf{0}$ & $\mathbf{0 . 0 0 \%}$ \\
\hline
\end{tabular}

Table 17 indicated that seventy-six percent $(76.47 \%)$ of the participants disagreed about the market plan for their sports teams at the Arab National Cub. Twenty-three percent $(23.53 \%)$ of the participants were neutral in there response about the market plan for their sports teams at the Arab National Cub.

Table 17: Marketing plan for your sport at the Arab Games

\begin{tabular}{|c|c|c|c|c|c|}
\hline \multicolumn{2}{|c|}{ Yes } & \multicolumn{2}{c|}{ Avg. } & \multicolumn{2}{c|}{ No } \\
\hline Frequency & Percentage & Frequency & Percentage & Frequency & Percentage \\
\hline 0 & $\mathbf{0 . 0 0 \%}$ & $\mathbf{8}$ & $\mathbf{2 3 . 5 3 \%}$ & $\mathbf{2 6}$ & $\mathbf{7 6 . 4 7 \%}$ \\
\hline
\end{tabular}

Table 18 showed that seventy-six percent (76\%) of the participants disagreed that the athletes or teams would qualify to go to the next Olympic Games. Eight percent $(8 \%)$ were neutral in response, or did not know if the athletes can make it to the upcoming Olympic Games.

Table 18: Your team players qualified to the next Olympic Game

\begin{tabular}{|c|c|c|c|c|c|}
\hline \multicolumn{2}{|c|}{ Yes } & \multicolumn{2}{c|}{ Avg. } & \multicolumn{2}{c|}{ No } \\
\hline Frequency & Percentage & Frequency & Percentage & Frequency & Percentage \\
\hline 0 & $\mathbf{0 . 0 0 \%}$ & $\mathbf{8}$ & $\mathbf{2 3 . 5 3 \%}$ & $\mathbf{2 6}$ & $\mathbf{7 6 . 4 7 \%}$ \\
\hline
\end{tabular}

\section{Discussion}

Fan identification, involvement opportunity, and reference groups were established as influential factors that had a significant impact on overall sports fans' involvement (Martin et al., 2009). Also, the results and the outcome from the interview was divided into questions about fan involvement, public relations, management, cultural issues, marketing efforts, and cooperation with sponsors. 
Sloan Sports Conference described the future of sports as HDTV vs. Live Events. The innovation of media and broadcasting technology has placed in-home viewing on a trajectory to rival or even surpass the experience of live viewing in the stadium. While sports are "HDTV-proof" for teams, their focus is on the future of the fan experience in the stadium or arena, (MIT Sloan Analytics Conference). We trust this will change the way fans encounter an amusement. At first, around 150 PDAs will be accessible to fans that watch diversions from one of the office's 94 extravagance suites, the press box, and the second deck VIP territory (Morell, 2000). Some schools have been developing new technology to help them increase the game's day experience. The Aggies at Texas A\&M have created an app that will help with the parking during football games. The app is part of another marketing plan to organize traffic surrounding Kyle Field, Lomax said and will provide on goers with the ability to pay ahead for parking. It is also expected to provide real-time information about traffic conditions, including bus routes and traffic congestion (Martinez, 2014). Management needs to increase the sports leadership mission for managing individual sports and concentrate more on the result for both kinds of games to make the difference.

Regarding cultural issues, there is an increase in the connection between society and sports. Therefore, the continuity of individual sport depends on the increasing number of fans from a sport, as well as social perspective. Moreover, it seems that individual sports have a great history and future for Egyptian Olympics sports.

The results of the interview regarding marketing efforts indicated that the sport situation market is changing more than ever before; thus, we need to improve market plans and campaigns. The marketing plan and drive will help to evaluate current issues and needs, as well as inform future planning. Fans need to know more about athletes; perhaps, recommending fans to attend practices of the individual's sports could help to promote and stimulate better attendance at individual sporting events. This recent study suggested that marketing for individual sports before the final competition should allow enough time for planning.

Results also indicated it is essential to (a) increase the outcome from the products of an individual sport, (b) encourage the sponsors to provide more support to successful athletes, who have the advantage in a different event (c) increase the market base-strategies by promoting fan's participation when athletes are young, and (d) use a long-term marketing plan because the change will take time to take place with all other variables in Egyptian society such as culture.

According to USA Today, everything from the lack of Wi-Fi to the price of the tickets all contributes to the reason even the most prominent football schools had seen their attendance decline. (Axon, 2015) "If the athletic 
administration wants to improve the game-day experience for alumni and fans, put up Wi-Fi hotspots" (Chang, 2014). With the focus on game day experience and attendance, Andrew Guerra performed a study with about 18,876 school students at thirty-two (32) conferences and revealed several key findings: Consideration in the sport, game operations, ticket affordability, and opponent and team stats were the most persuasive in students' decision whether to attend a sporting event or not (Axon, 2015). If Egyptian organizers use the correct marketing plan, it may help them to see a better comparison of fan attendance in different sporting events.

\section{Conclusion}

Fans attend a sports competition because of the excitement. Therefore, changes in the rules for individual sports events could make these types of sports events more exciting to attend. The principal purpose of the study was to investigate factors that successfully attract fans attendance at individual sporting events in Egypt. Results indicated that seventy-six percent $(76.4 \%)$ of the participants disagreed about the market plan for their sports teams at the Arab National Cub, and twenty-three percent (23.5\%) disgreed. Results also indicated that forty-one percent $(41 \%)$ of participants agreed there was a delay in sending results to the media, and fifty-eight percent $(58 \%)$ of the coaches disagreed that they knew whether conference results were delivered late to the press.

Media coverage, public relations, social and cultural factors, management, and operation of the Egyptian sports national governing bodies play a vital role for fans' support to attend those different individual sporting events in Egypt. The study results indicated that fifty-five percent $(55 \%)$ of the participants disagreed whether there was support from the federation in these sports events, and forty-four percent $(44.1 \%)$ did not know the amount of support individual sports received from their national league.

The result of this study will be beneficial for the Egyptian government to implement a marketing plan effectively, and to promote individual sporting events in Egypt, also hopefully it could further increase the participation rate of individual sports at the Olympic Games.

\section{References:}

1. Abdnour, Erica. (10 Dec. 2017). In- Stadium Sports Fan Experience Summit Discussions to Focus on Game Day Initiatives, Incentives. PR.com 20 May. Business Insights: Essentials. Web. Accessed 3 Dec. 2017.

2. Aly, E. R. (2014). Study The Role Of Mass Sports And Physical Activity In A Healthy Egyptian Society. Retrieved from https://eujournal.org/index.php/esj/article/view/4196. 
3. Armstrong, K. (2007). Self, situations, and sport consumption: An exploratory study of symbolic interactionism. Journal of Sport Behavior, 30(2), 111-129.

4. Armstrong, \& Kolter. (n.d.). Summary Principles Marketing. Retrieved December 29, 2018, from https://www.worldsupporter.org/en/chapter/41521-summaryprinciples-marketing-armstrong-kotler

5. Axon, R. (2015, June 19). Study offers ideas on how to get students to games and keep them there. https://www.usatoday.com/story/sports/ncaaf/2015/06/19/collegefootball-how-to-fix-student-attendance-decline/29007681/. Accessed 18 Oct. 2017.

6. Barian, G. S., \& Zach, S. (2018). A Conceptual Framework for Retro Marketing in Sport. Sport Marketing Quarterly, 27(3), 197-2010.

7. Casey D. (1988). The sports Development Continuum. The Scottish Sport Council.

8. Chang, Kenneth. (16 Oct. 2014). Gameday experience in need of serious reform. UWIRE Text, p. 1. Expanded Academic ASAP, link.galegroup.com/apps/doc/A386249671/EAIM?u=tall18692\&sid= EAIM\&xid=70cce6ec. Accessed 7 Dec. 2017.

9. Cohen, Ben. "Declining Student Attendance Hits Georgia; at Campuses Across the Country,More Reasons than Ever to Skip the Game." Wall Street Journal (Online) Sep 26, 2013. ProQuest. Web. 15 Oct. 2017.

10. Choi, Y., Martin, J., Park, M., \& Yoh, T. (2009). Motivational Factors Influencing Sport Spectator Involvement At NCAA Division II Basketball Games. Journal for the Study of Sports and Athletes in Education, 3(3), 265-284. doi:10.1179/ssa.2009.3.3.265

11. Community Development and Sport Participant. By: Vail, Susan E. Journal of Sport Management, Oct 2007, Vol.21 Issues 4, p571$596,26 p$,

12. Egypt produces squash champions, January 14, 2008, http://www.npr.org

13. Dodd, Suzanne M. (1997). The effectiveness of embedded sponsorship stimuli on sport spectators. Florida state university Ph.D. 106p.

14. Egypt Produces Squash Champions. (2008, January 14). Retrieved from

https://www.npr.org/templates/transcript/transcript.php?storyId=1807 6145

15. Falls, G., \& Natke., P. (2014). College football attendance: a panel study of the Football Bowl Subdivision. Applied Economics, s, 46 
(10), 1093-1107. http://dx.doi.org/10.1080/00036846.2013.866208. Accessed 27 Nov.2017.

16. Falls, Gregory A., and Paul A. Natke. (2015). College Football Attendance: A Panel Study of The Football Championship Subdivision. Managerial and Decision Economics 37.8: 530-540. Web. Accessed 27 Nov.2017.

17. Fullerton, S., \& Merz, G. R. (2008). The four domains of sports marketing: A conceptual framework. Retrieved from https://commons.emich.edu/mktg_facsch/26/.

18. "Good but could be better". Al-Ahram. Retrieved 2012-07-29.

19. Guerra, Andrew. "Student Attendance at Collegiate Sporting Events." Journal of National Association of Collegiate Marketing Administrators ed. June 2015. Web 15 Oct 2017

20. IOC. (2018, August 22). Egypt - National Olympic Committee (NOC). Retrieved from https://www.olympic.org/egypt

21. Klein, Jeff Z. (2007-09-20). "Women's Soccer, Egyptian Men, and What Is 'Forbidden' - NYTimes.com". Goal.blogs.nytimes.com. Retrieved 2012-08-02.

22. Mazhar, Inas (2004-03-30). "BBC SPORT | Football | African | Egyptian woman honoured”. BBC News. Retrieved 2012-08-02.

23. Martinez, P. (2014). App designed to change game day experience. UWIRE Text. Accesses 7 Dec. 2017.

24. Morell, John. (4 Sept. 2000). Wireless Technology Will Enhance Game Day Experience At 3Com Park. Amusement Business, p.13.s, Business Collection, http://link.galegroup.com/apps/doc/A65106064/ITBC?u=tall18692\& sid=ITBC\&xid=412a0dc9. Accesses 10 Dec. 2017.

25. Motivational profiles of sport fans of different sports. Wann, Daniel L.; Grieven, Frederick G.; Zapalac, Ryan K.; Pease, Dale G., Sport Marketing Quarterly 2008, Vol.17 Issue 1, p6

26. P.C Chan and Don DeGraaf, (1998). Family campinging Hong Kong .the official magazine Of the international council for health, physical education, recreation, and dance.vol.xxxv, no.1, fall 24-27

27. Popke .m.(2003) Marketing high school sports, Journal of sport management: Apr vol.17issue 2,p191,2p

28. Revolvy, L. (n.d.). "List of football stadiums in Egypt" on Revolvy.com. Retrieved from https://www.revolvy.com/page/List-offootball-stadiums-in-Egypt

29. Shackelford, D.E., \& Greenwell, T. (2005). Predicting Women's Division I Sports Attendance: An Analysis of Institutional Characteristics. 
30. "Soccer Pioneer Builds Her Own Revolution In Egypt". NPR. Retrieved 2012-07-29.

31. Sopher, P. (2014, November 22). Why Egypt Crushes at Squash. Retrieved from https://www.theatlantic.com/international/archive/2014/11/whyegypt-crushes-at-squash/383062/

32. "The Future of the Game Day Experience: HDTV vs. Live Events." MIT Sloan Analytics Conference, www.sloansportsconference.com/content/the-future-of-the-gameday-experience-hdtv-vs-live-events/. Accessed 3 Dec. 2017.

33. Today, E. (n.d.). Medals are great, but not enough for Egyptian athletes. Retrieved July 27, 2018, from http://www.egypttoday.com/Article/8/54803/Medals-are-great-butnot-enough-for-Egyptian-athletes

34. Trail, G. T., Anderson, D. F., \& Fink, J. S. (2005). Consumer satisfaction and identity theory: A model of sport spectator conative loyalty. Sport Marketing Quarterly, 14(2), 98-111.

35. Weiss, M.R.; Hayashi, C.T., (1995). Pediatric Exercise Science Feb: Vol. 7 Issue 1. p. 36-48

\section{Appendix I}

\begin{tabular}{|c|c|c|c|c|}
\hline $\begin{array}{l}\text { Olympic } \\
\text { Games }\end{array}$ & Discipline & Events & Med. & Name / Team \\
\hline $\begin{array}{l}\text { Amsterdam } \\
1928\end{array}$ & Diving & $10 \mathrm{~m}$ platform Men & S & Simaika, Farid \\
\hline $\begin{array}{l}\text { Amsterdam } \\
1928\end{array}$ & Diving & $3 \mathrm{~m}$ springboard Men & $\mathrm{B}$ & Simaika, Farid \\
\hline $\begin{array}{l}\text { Amsterdam } \\
1928\end{array}$ & Weightlifting & $\begin{array}{l}75-82.5 \mathrm{~kg} \text {, total (light- } \\
\text { heavyweight) Men }\end{array}$ & G & Nosseir, El sayed Mohamed \\
\hline $\begin{array}{l}\text { Amsterdam } \\
1928\end{array}$ & $\begin{array}{l}\text { Wrestling } \\
\text { Greco-Roman }\end{array}$ & $\begin{array}{l}75-82.5 \mathrm{~kg} \text { (light- } \\
\text { heavyweight) Men }\end{array}$ & G & Moustapha, Ibrahim \\
\hline Berlin 1936 & Weightlifting & $\begin{array}{c}-60 \mathrm{~kg}, \text { total (featherweight) } \\
\text { Men }\end{array}$ & S & Soliman, Saleh Mohamed \\
\hline Berlin 1936 & Weightlifting & $\begin{array}{c}-60 \mathrm{~kg} \text {, total (featherweight) } \\
\text { Men }\end{array}$ & B & Shams, Ibrahim Hassanein \\
\hline Berlin 1936 & Weightlifting & $\begin{array}{c}60-67.5 \mathrm{~kg}, \text { total (lightweight) } \\
\text { Men }\end{array}$ & G & $\begin{array}{c}\text { Mesbah, Anwar Mohamed } \\
\text { Ahmed }\end{array}$ \\
\hline
\end{tabular}




\begin{tabular}{|c|c|c|c|c|}
\hline Berlin 1936 & Weightlifting & $\begin{array}{l}67.5-75 \mathrm{~kg} \text {, total } \\
\text { (middleweight) Men }\end{array}$ & G & Eltouny, Khadr El Sayed \\
\hline Berlin 1936 & Weightlifting & $\begin{array}{l}75-82.5 \mathrm{~kg} \text {, total (light- } \\
\text { heavyweight) Men }\end{array}$ & B & Wasif, Ibrahim \\
\hline $\begin{array}{l}\text { London } \\
1948\end{array}$ & Weightlifting & $\begin{array}{c}56-60 \mathrm{~kg} \text {, total } \\
\text { (featherweight) Men }\end{array}$ & G & Fayad, Mahmoud \\
\hline $\begin{array}{l}\text { London } \\
1948\end{array}$ & Weightlifting & $\begin{array}{c}60-67.5 \mathrm{~kg}, \text { total (lightweight) } \\
\text { Men }\end{array}$ & G & Shams, Ibrahim Hassanein \\
\hline $\begin{array}{c}\text { London } \\
1948\end{array}$ & Weightlifting & $\begin{array}{c}60-67.5 \mathrm{~kg}, \text { total (lightweight) } \\
\text { Men }\end{array}$ & $S$ & Hamouda, Attia Mohamed \\
\hline $\begin{array}{c}\text { London } \\
1948\end{array}$ & $\begin{array}{l}\text { Wrestling } \\
\text { Greco-Roman }\end{array}$ & $\begin{array}{c}52-57 \mathrm{~kg} \text { (bantamweight) } \\
\text { Men }\end{array}$ & $S$ & Hassan Ali, Mahmoud \\
\hline $\begin{array}{c}\text { London } \\
1948\end{array}$ & $\begin{array}{c}\text { Wrestling } \\
\text { Greco-Roman }\end{array}$ & $\begin{array}{c}79-87 \mathrm{~kg} \text { (light-heavyweight) } \\
\text { Men }\end{array}$ & B & Orabi, Ibrahim \\
\hline $\begin{array}{l}\text { Helsinki } \\
1952\end{array}$ & $\begin{array}{c}\text { Wrestling } \\
\text { Greco-Roman }\end{array}$ & 57 - $61 \mathrm{~kg}$ (featherweight) Men & B & Rashed, Abdel aal Ahmed \\
\hline Rome 1960 & Boxing & - 51kg (flyweight) Men & B & El gindy, Abdel moneim \\
\hline Rome 1960 & $\begin{array}{c}\text { Wrestling } \\
\text { Greco-Roman }\end{array}$ & - 52kg (flyweight) Men & S & Sayed, Osman \\
\hline $\begin{array}{c}\text { Los } \\
\text { Angeles } \\
1984\end{array}$ & Judo & open category Men & $\mathrm{S}$ & Rashwan, Mohamed \\
\hline $\begin{array}{l}\text { Athens } \\
2004\end{array}$ & Boxing & $\begin{array}{c}+91 \mathrm{~kg} \text { (super heavyweight) } \\
\text { Men }\end{array}$ & S & Aly, Mohamed \\
\hline $\begin{array}{l}\text { Athens } \\
2004\end{array}$ & Boxing & $\begin{array}{c}75-81 \mathrm{~kg} \text { (light-heavyweight) } \\
\text { Men }\end{array}$ & $\mathrm{B}$ & Ismail, Ahmed \\
\hline $\begin{array}{l}\text { Athens } \\
2004\end{array}$ & Boxing & $81-91 \mathrm{~kg}$ (heavyweight) Men & $\mathrm{B}$ & elsayed, mohamed \\
\hline $\begin{array}{l}\text { Athens } \\
2004\end{array}$ & Taekwondo & $-58 \mathrm{~kg}$ Men & B & Bayoumi, Tamer \\
\hline Athens & Wrestling & 84 - 96kg Men & $\mathrm{G}$ & Ibrahim, Karam \\
\hline
\end{tabular}




\section{Appendix II}

\section{Survey Results}

\begin{tabular}{|c|c|c|c|c|c|c|}
\hline & \multicolumn{2}{|c|}{ Yes } & \multicolumn{2}{|c|}{ Avg. } & \multicolumn{2}{|c|}{ No } \\
\hline & Frequency & Percentage & Frequency & Percentage & Frequency & Percentage \\
\hline $\begin{array}{l}\text { 1. Is there is fewer media } \\
\text { coverage for individual } \\
\text { sports than a team sport? }\end{array}$ & 30 & $88.24 \%$ & 0 & $0.00 \%$ & 4 & $11.76 \%$ \\
\hline $\begin{array}{c}\text { 2. Is there any } \\
\text { relationship between } \\
\text { public relations and } \\
\text { individual sports? }\end{array}$ & 16 & $47.06 \%$ & 18 & $52.94 \%$ & 0 & $0.00 \%$ \\
\hline $\begin{array}{c}\text { 3a Is There any } \\
\text { coordination in work } \\
\text { between you and team } \\
\text { manager from } \\
\text { A -Media cover. } \\
\end{array}$ & 0 & $0.00 \%$ & 14 & $41.18 \%$ & 20 & $58.82 \%$ \\
\hline $\begin{array}{c}\text { 3b.Is There any } \\
\text { coordination in work } \\
\text { between you and the } \\
\text { team manager from b- } \\
\text { Transport all results for } \\
\text { media directly. }\end{array}$ & 14 & $41.18 \%$ & 20 & $58.82 \%$ & 0 & $0.00 \%$ \\
\hline $\begin{array}{c}\text { 3c Is There any } \\
\text { coordination in work } \\
\text { between you and team } \\
\text { manager from } \\
\text { c- They are late sending } \\
\text { the result to the media. }\end{array}$ & 14 & $41.18 \%$ & 20 & $58.82 \%$ & 0 & $0.00 \%$ \\
\hline $\begin{array}{l}\text { 4Is the spectator they } \\
\text { know how much effort } \\
\text { the individual sports } \\
\text { from training teams until } \\
\text { this result come like this } \\
\text { or we need more public } \\
\text { relations to clear this } \\
\text { effort to the audience to } \\
\text { come to attend the } \\
\text { competition or the } \\
\text { games? }\end{array}$ & 0 & $0.00 \%$ & 4 & $11.76 \%$ & 30 & $88.24 \%$ \\
\hline $\begin{array}{l}5 \text { The attending people } \\
\text { for the events are form } \\
\text { the fans. }\end{array}$ & 14 & $41.18 \%$ & 0 & $0.00 \%$ & 20 & $58.82 \%$ \\
\hline $\begin{array}{l}6 \text { Is the Arab Game Cub } \\
\text { will organize for people } \\
\text { attending the events? }\end{array}$ & 9 & $26.47 \%$ & 25 & $73.53 \%$ & 0 & $0.00 \%$ \\
\hline $\begin{array}{c}7 \text { Is your sport is } \\
\text { famous? }\end{array}$ & 30 & $88.24 \%$ & 4 & $11.76 \%$ & 0 & $0.00 \%$ \\
\hline $\begin{array}{l}8 \text { Is there any relation } \\
\text { between less attends and } \\
\text { promote your game? }\end{array}$ & 28 & $82.35 \%$ & 6 & $17.65 \%$ & 0 & $0.00 \%$ \\
\hline $\begin{array}{l}9 \text { Is your sport has the } \\
\text { same chance to get } \\
\text { famous as others? }\end{array}$ & 25 & $73.53 \%$ & 9 & $26.47 \%$ & 0 & $0.00 \%$ \\
\hline $\begin{array}{c}\text { 10 Egypt has enough } \\
\text { good sports facilities for } \\
\text { the competition, } \\
\text { especially individual } \\
\text { sports. }\end{array}$ & 28 & $82.35 \%$ & 6 & $17.65 \%$ & 0 & $0.00 \%$ \\
\hline
\end{tabular}




\begin{tabular}{|c|c|c|c|c|c|c|}
\hline $\begin{array}{c}\text { 11 Do you agree about } \\
\text { the number of people } \\
\text { who attend the Arab } \\
\text { games? }\end{array}$ & 0 & $0.00 \%$ & 10 & $29.41 \%$ & 24 & $70.59 \%$ \\
\hline $\begin{array}{l}12 \text { Do you have all the } \\
\text { support from your } \\
\text { federation in this } \\
\text { competition? }\end{array}$ & 0 & $0.00 \%$ & 15 & $44.12 \%$ & 19 & $55.88 \%$ \\
\hline $\begin{array}{l}13 \text { Are the Arab game } \\
\text { well organized for the } \\
\text { players in your team? }\end{array}$ & 25 & $73.53 \%$ & 9 & $26.47 \%$ & 0 & $0.00 \%$ \\
\hline $\begin{array}{l}14 \text { Does Egypt need more } \\
\text { stadiums and sports } \\
\text { facilities? }\end{array}$ & 20 & $58.82 \%$ & 10 & $29.41 \%$ & 4 & $11.76 \%$ \\
\hline $\begin{array}{c}15 \text { Did Egyptian } \\
\text { stadiums need to improve } \\
\text { and development? }\end{array}$ & 20 & $58.82 \%$ & 10 & $29.41 \%$ & 4 & $11.76 \%$ \\
\hline $\begin{array}{c}16 \text { Do you have sports } \\
\text { manager for your teams? }\end{array}$ & 25 & $73.53 \%$ & 9 & $26.47 \%$ & 0 & $0.00 \%$ \\
\hline $\begin{array}{l}17 \text { Is the contact between } \\
\text { individual games and } \\
\text { media coverage enough? }\end{array}$ & 0 & $0.00 \%$ & 8 & $23.53 \%$ & 26 & $76.47 \%$ \\
\hline $\begin{array}{l}18 \text { Do you think that Not, } \\
\text { enough courage people to } \\
\text { come to attend the event } \\
\text { affects individual sport } \\
\text { continuous? }\end{array}$ & 30 & $88.24 \%$ & 4 & $11.76 \%$ & 0 & $0.00 \%$ \\
\hline $\begin{array}{l}19 \text { Is it your country the } \\
\text { same less attendance of } \\
\text { individual games? }\end{array}$ & 31 & $91.18 \%$ & 3 & $8.82 \%$ & 0 & $0.00 \%$ \\
\hline $\begin{array}{c}20 \text { Do we have good } \\
\text { media coverage for an } \\
\text { individual game in this } \\
\text { competition you } \\
\text { attending with your team } \\
\text { in Egypt? } \\
\end{array}$ & 0 & $0.00 \%$ & 6 & $17.65 \%$ & 28 & $82.35 \%$ \\
\hline $\begin{array}{c}21 \text { Is the ticket coast is } \\
\text { suitable for the } \\
\text { individual event in Arab } \\
\text { games? }\end{array}$ & 30 & $88.24 \%$ & 4 & $11.76 \%$ & 0 & $0.00 \%$ \\
\hline $\begin{array}{l}22 \text { Do you agree about } \\
\text { the market plan for your } \\
\text { sports in Arab games? }\end{array}$ & 0 & $0.00 \%$ & 8 & $23.53 \%$ & 26 & $76.47 \%$ \\
\hline $\begin{array}{l}23 \text { Do we need to increase } \\
\text { the fans for your sport? }\end{array}$ & 33 & $97.06 \%$ & 1 & $2.94 \%$ & 0 & $0.00 \%$ \\
\hline $\begin{array}{c}\text { 24Do you have less } \\
\text { attendance in your sport? }\end{array}$ & 29 & $85.29 \%$ & 5 & $14.71 \%$ & 0 & $0.00 \%$ \\
\hline $\begin{array}{l}\text { 25Do you have marketing } \\
\text { plan for your team? }\end{array}$ & 17 & $50.00 \%$ & 17 & $50.00 \%$ & 0 & $0.00 \%$ \\
\hline $\begin{array}{c}\text { 26Is your sport famous } \\
\text { enough to attend? }\end{array}$ & 5 & $14.71 \%$ & 5 & $14.71 \%$ & 24 & $70.59 \%$ \\
\hline $\begin{array}{l}\text { 27Are any players in } \\
\text { your team qualified to go } \\
\text { the next Olympic game? }\end{array}$ & 30 & $88.24 \%$ & 4 & $11.76 \%$ & 0 & $0.00 \%$ \\
\hline
\end{tabular}

